\title{
Ultrastructure of bone marrow cells in patients with autoimmune pathologies
}

\author{
Galina Fedotovskikh ${ }^{1}$, Galiya Shaimardanova ${ }^{2}$, Manarbek Askarov ${ }^{3}$, Sapargul Marat ${ }^{4}$, Tatyana Yezhelenko ${ }^{4}$
}

${ }^{1}$ Scientific and Research Laboratory, National Scientific Medical Center, Astana, Republic of Kazakhstan

${ }^{2}$ Scientific Research Management Department, National Scientific Medical Center, Astana, Republic of Kazakhstan ${ }^{3}$ Center of Cellular Technologies and Transplantation, National Scientific Medical Center, Astana, Republic of Kazakhstan

${ }^{4}$ Scientific and Research Laboratory, National Scientific Medical Center, Astana, Republic of Kazakhstan

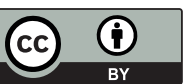

This work is licensed under a Creative Commons Attribution 4.0 International License

Received: 2018-01-30

Accepted: 2018-02-02

UDC: 616.1

\section{J Clin Med Kaz 2018;1(47):49-52}

Corresponding Author: Sapargul Marat, junior research fellow, Scientific and Research Laboratory, National Scientific Medical Center, Astana, Kazakhstan. Tel.:+77011986459,

+7 (7172) 57-76-59;

\section{Abstract}

Objective: To determine the morpho-functional state of bone marrow autologous cells at the ultrastructural level.

Material and Methods: For the electron microscopic examination, bone marrow cells taken from patients with autoimmune diseases were fixed in a $2.5 \%$ solution of glutaraldehyde with post fixation in a $1 \%$ solution of osmium tetroxide, was performed according to the conventional method and enclosed in epon. Ultrathin sections were prepared on a Leica ultramicrotome, contrasted with lead citrate by Reynolds, and examined in an electron microscope called Libra 120 (C. Zeiss).

Results: Morpho-functional state of autologous bone marrow cells in severe chronic pathology was characterized by mitochondrial dysfunction and signs of insufficiency of microvesicular secretory function.

Conclusion: Precultivation of bone marrow cells of patients with severe autoimmune diseases restored the energetic function of mitochondria, increased the secretory activity of endosomes.

Keywords: bone marrow cells, transplantation, morphology

\section{АУТОИММУНДЫ ПАТОЛОГИЯЛЫ НАУКАСТАРДЫН СУЙЕК КЕМІГІ ЖАСУШАЛАРЫНЫҢ УЛЬТРАҚҰРЫЛЫМДЫҚ СИПАТТАМАСЫ \\ Федотовских Г.В. ${ }^{1}$, Шаймарданова Г.М. ${ }^{2}$, Асқаров М.Б. ${ }^{3}$, Марат С. ${ }^{4}$, Ежеленко Т.Г. ${ }^{4}$ \\ 'Ғылыми-зерттеу зертханасы, Ұлттық ғылыми медициналық орталық, Астана, Қазақстан Республикасы \\ ²Ғылыми зерттеулер менеджменті бөлімі, Ұлттық ғылыми медициналық орталык, Астана, Қазақстан Республикасы \\ З3асушалық технология және трансплантаттау орталығы, Ұлттық ғылыми медициналық орталық, Астана, Қазақстан Республикасы \\ ${ }^{4}$ Ғылыми-зерттеу зертханасы, Ұлттық ғылыми медициналық орталық, Астана, Қазақстан Республикасы}

\section{ТҰЖЫРЫМДАМА}

Мақсаты: Ультрақұрылымдық деңгейде аутологиялық сүйек кемігіжасушаларының морфо-функционалды жағдайын зерттеу.

Әдістері: Электронды микроскопиялық зерттеулер үшін жасушалар 2,5\%-ды глютаральдегид ерітіндісінде фриксацияланды, екінші реттік фиксация 1\%-ды осьмий қышқылымен жүргізіліп, материал әріқарай дәстүрлі әдістеме бойынша ероп-ға құйылды. Жартылайжұқа және ультражұқа тілімдер Leica ультрамикротомында кесіліп,метилен көгі, азур-2 және негізгі фуксинмен боялды. Ультражұқа тілімдер Рейнольдс әдістемесіне сәйкес контрастіленді. Зерттеулер Carl Zeiss фрирмасы ұсынған Libra 120 электронды микроскопы көмегімен жүргізілді.

Нәтижелері: Ауыр созылмалы патологиялы аутологиялық сүйеккемігіжасушаларының морфо-функционалдыжағдайы митохондриялық дисфункциямен және микровезикулярлы секреторлы функцияның жетіспеушілігімен сипатталды. 
Қорытынды: Аутоиммунды аурулары бар науқастардан алынғын сүйек кемігін прекультивирлеу митохондриялардың энергетикалық қызметін қалпына келтіріп, эндосомалардың секреторлық белсенділігін арттырып, зақымдалған жасушаларды жоюға көмектеседі.

Негізгі сөздер: сүйек кемігі жасушалары, трансплантация, морфология

\section{УЛЬТРАСТРУКТУРА КЛЕТОК КОСТНОГО МОЗГА БОЛЬНЫХ С АУТОИММУННОЙ ПАТОЛОГИЕЙ}

Федотовских Г.В. ${ }^{1}$, Шаймарданова Г.М. ${ }^{2}$, Аскаров М.Б. ${ }^{3}$, Марат С. ${ }^{4}$ Ежеленко Т.Г. ${ }^{4}$

'Научно-исследовательская лаборатория, Национальный научный медицинский центр, Астана, Республика Казахстан

${ }^{2}$ Отдел менеджмента научных исследований, Национальный научный медицинский центр, Астана, Республика Казахстан

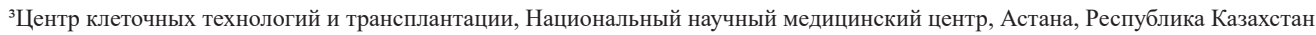

${ }^{4}$ Научно-исследовательская лаборатория, Национальный научный медицинский центр, Астана, Республика Казахстан

\section{PEЗЮME}

Цель: Определить на ультраструктурном уровне морфофрункциональное состояние аутологичных клеток костного мозга.

Материалы и методы: Для электронно-микроскопического исследования, клетки костного мозга, взятые у больных с аутоиммунными заболеваниями фиксировали в 2,5\% растворе глютаральдегид с пост фиксацией в $1 \%$ растворе четырех окиси осмия, проводили по общепринятой методике и заключали в эпон. Ультратонкие срезы готовили на ультрамикротоме Leica, контрастировали цитратом свинца по Рейнольдсу, исследовали в электронном микроскопе Libra 120 (C. Zeiss).

Результаты: Морфофункциональное состояние аутологичных клеток костного мозга при тяжелой хронической патологии характеризовалось дисфункцией митохондрий и признаками недостаточности микро везикулярной секреторной функции.

Выводы: Пре культивирование клеток костного мозга больных с тяжелыми аутоиммунными заболеваниями восстанавливало энергетическую функцию митохондрий, повышало секреторную активность эндосом.

Ключевые слова: клетки костного мозга, трансплантация, морфология

\section{Kipicne}

Қазіргі таңда регенераторлық жасуша терапиясының қарқынды дамуына қарамастан, көптеген механизмдері мен технологиялық эффектілерінің жүзеге асу жолдары толық зерттелмеген және ғылыми тұрғыда негізделмеген.

Ұзақ созылмалы патологиялы науқастардан келесі культивирлеуге алынған аутологиялық сүйек кемігі жасушалары биорегуляторлық белсенділіктің төмендеуімен сипатталып, сондай - ақ бейімделушілік өсу ұлпаспецификалық факторлардың төмендеуіне байланысты жасушалық терапияғы жарамсыз болатыны белгілі [1,2]. Алайда, науқастардың сүйек кемігі жасушаларының функционалдық жағдайының тежелуінің патологиялық механизмдері соңына дейін анықталмаған.

Әртүрлі патологиялық аурулардың терапиясында қолданылатын жасушалар популяцияларын культивирлеп, аутологиялық трансплантаттарды қайта еңгізу барысында жасушалардың морфологиялық жағдайын бағалау өте маңызды [3]. Қазіргі таңда әдебиеттер көзінде аутологиялық сүйек кемігі жасушаларының культивирлеуден кейінгі ультрақұрылымдық деңгейдегі морфологиялық қасиеттері жайында мәліметтер жоқ.

\section{Мақсаты}

Ультрақұрылымдық деңгейде аутологиялық сүйек кемігі жасушаларының морфо-функционалды жағдайын зерттеу

\section{Әдістері}

Сүйек кемігі жасушаларын бөлу үшін науқастар арнайы клинико-зертханалық зерттеулерден өтеді. Науқастан сүйек кемігін алу стационарлық жағдайда, анестизия көмегімен жасалады. Әртүрлі патологиялық ауытқулары бар 33 науқастан аспирациялық әдіс көмегімен мықын сүйегінен 400 мл көлемінде сүйек кемігі бөлініп алынды. Центрифугаланған жасуша суспензиясынан артық сұйықтық бөлініп алныады. Қалған жасушалы тұнбаға арнайы қоректік орта құйылып, СО2 инкубаторында 48 сағат арнайы матрасстардакультивирленді. Жасушалардын белгілі бөлігі культивирлеуге дейінгі морфологиялық зерттеулер жасалу үшін бөлініп алынды. Сүйек кемігі жасушаларын 48 сағат культивирленгеннен кейін науқастарға тамырішілік орта есеппен 140×106мөлшерінде трансплантацияланды. Культивирленген жасушалардың аз бөлігі культивирлеуден кейінгі морфологиялық зерттеулерге алынды. Электронды микроскопиялық зерттеулер үшін жасушалар 2,5\%-ды глютаральдегид ерітіндісінде фиксацияланды, екінші реттік фиксация 1\%-ды осьмий қышқылымен жүргізіліп, материал әріқарай дәстүрлі әдістеме бойынша еpon ға құйылды. Жартылайжұқа және ультражұқа тілімдер Leica ультрамикротомында кесіліп,метилен көгі, азур-2 және негізгі фуксинмен боялды. Ультражұқа тілімдеруранилацетатпен және қорғасын цитратты Рейнольдсқа сәйкес контрастіленді. Ультрақұрылымдық зерттеулер Carl Zeiss фирмасы ұсынғанLibra 120 электронды микроскопы көмегімен жүргізілді.

\section{Нәтижелері}

Созылмалы ауыр патологиясы бар науқастардан алынған аутогенді сүйек кемігі жасушалары арасында тиісті морфологиялық құрылымды полиморфизмді діңгек жасушалары сондай - ақ прогениторлы, дифференцирленген жасушалардың гетерогенді популяциялары анықталды (Сурет 1).

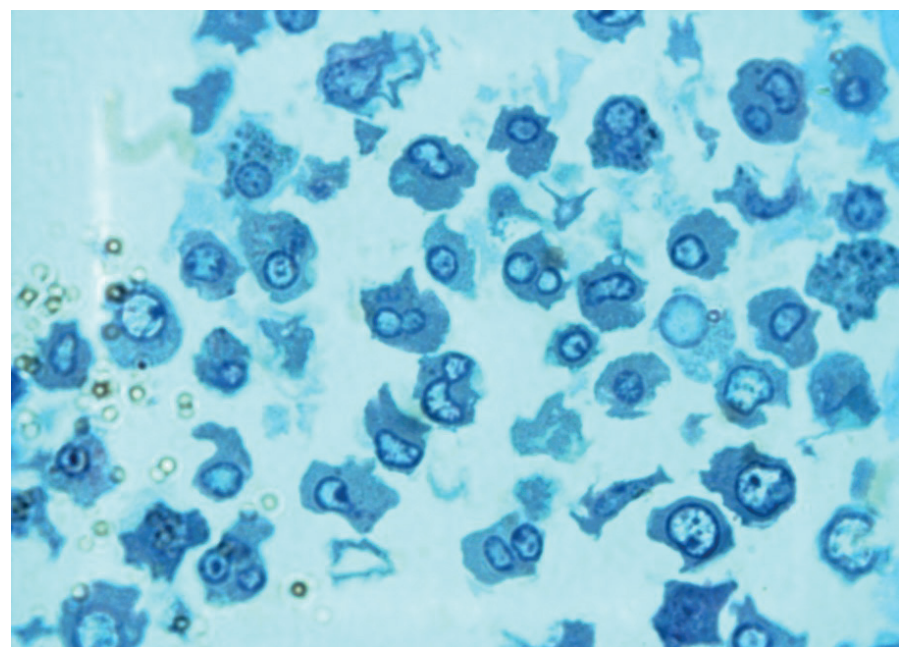

Сурет 1 - Культивирлеуге дейінгі сүйек кемігі жасушалары. Жартылай жұқа тілім. Ұлғ х 1000 есе. 
Алғашқы 3 класс тобына жататын жасушалар морфологиялық тұрғыдан ажыратылмайтын жасушалар және кіші, орташа гиперхромды ядросы мен базофильді боялған цитоплазмамен ерекшеленген лимфоциттер сирек кездесті.

Жарық-оптикалық деңгейде бластты жасушалар сирек кездесті. Бластты жасушалар көлемі ірі, әрі ашық түсті 2-4 ядрошықтары бар тегіс емес ядролы жасушалар тобы.

Гранулоцитарлы өскін жасушасы жарық оптикалық деңгейде цитоплазматикалық шіктілікке ие, оның ерекшелігі бойынша олар нейтрофильді, базофильді және эозинофильді болады.

Электронды микроскопиялық промиелоциттердің бірдей деңгейде орналаспаған ірі ядросы бар хроматин жіптері мен ұсақ ядрошықтары болады. Электронды перинуклеардыкеңістік тығыздығы төмендейді. Нейтрофильді промиелоцит цитоплазмасы көптеген сферикалық пішінді гомогенді түйіршіктермен толтырылған, мембрана немесе вакуоль ішінде орналасқан күйінде кездеседі.

Түйіршіктелген эндоплазматикалық ретикулум цистерналарының (ТЭГ) пішіні ұзынша және жалпақтау келген. Жарық түсірілген кезде ГЭР қауыз тәріздес құрамды болады. Фиксирленген рибосомалар түсіріледі. Митохондрия саны көп емес және көлемі де шағын, осмиофильді матрикс пен электронды мөлдір кристаларға ие.

Электронды микроскопиялық күйде цитоплазмада электронды тығыздығы төмен болып келетін айрықша түйіршіктер анықталды. Митохондриялар саны көп емес. ГЭР көбіктерінен тұрды. Сонымен бірге фиксирленген және де еркін рибосомалар да анықталды.

Электронды микроскопиялық тұрғыдан нейтрофильді метамиелоцит цитоплазмасында электрондылық тығыздығы арта түскен түйіршіктер орналасқан. ГЭР каналдары қысқа тары және жарық түсірілген кезде аздап кеңейе түскен.

Перинуклеарлы кеңістік тары, ядроның айналасындағы цитоплазма аумағы ашық. Көптеген түйіршіктер азурофильді және айрықша түйіршіктер қатарына жатады. ГЭР канальцалары қысқа болды, матриксті митохондрияның электронды тығыздығы төмен және аздаған кристалар кездеседі.

Моноцитарлы өскін жасушасы сирек кездесетін промоноциттер ретінде белгілі. Лимфоцитарлы өскін жасушасы барынша көп түрде кездеседі. Алайда пролимфоциттер сирек кездеседі. Бұлар дөңгеленген бозғылт ядролы және нәзік сеткалы хроматині бар үлкен емес жасушалар. Электронды микроскопиялық тұрғыда конденсирленген хроматин ядросы жіңішке таспамен айшықталған. Ядроның қасына центросома орналасқан. Органеллалар саны көп емес. Гольджи кешенінің элементтері кеңейген.

Iрі митохондриялар сопақша және созылған пішінде конденсирленген типке тиесілі, олардың электронды мөлдір кеңейген кристалары бар. Митохондрия бөліктерінің фрагментирленген кристалары бар және құрылымдық жағынан өзгерістерге ұшыраған митохондриалды мембраналары кездеседі. Iрі және ұсақ вакуолалар жарылған ұсақ көбіктердің қауыз тәріздес эндосомалары - экзосомдары болады. ГЭР канальцаларының ұсақ сақина пішіндес, саны көп емес, жартылай белгіленген рибосомаларынан айрылған жасушалары бар. Еркін рибосомалары көп.

\section{Электронды}

хроматин күйінде орналасқан. Iрі митохондрияның осмиофильді матрикс пен кеңейтілген деформацияға ұшыраған кристалары бар лимфоцит ГЭР каналдары әлсіз дамыған, кеңейген, бұрыс пішінді және кіріккен рибосомалары болады (Сурет 2).

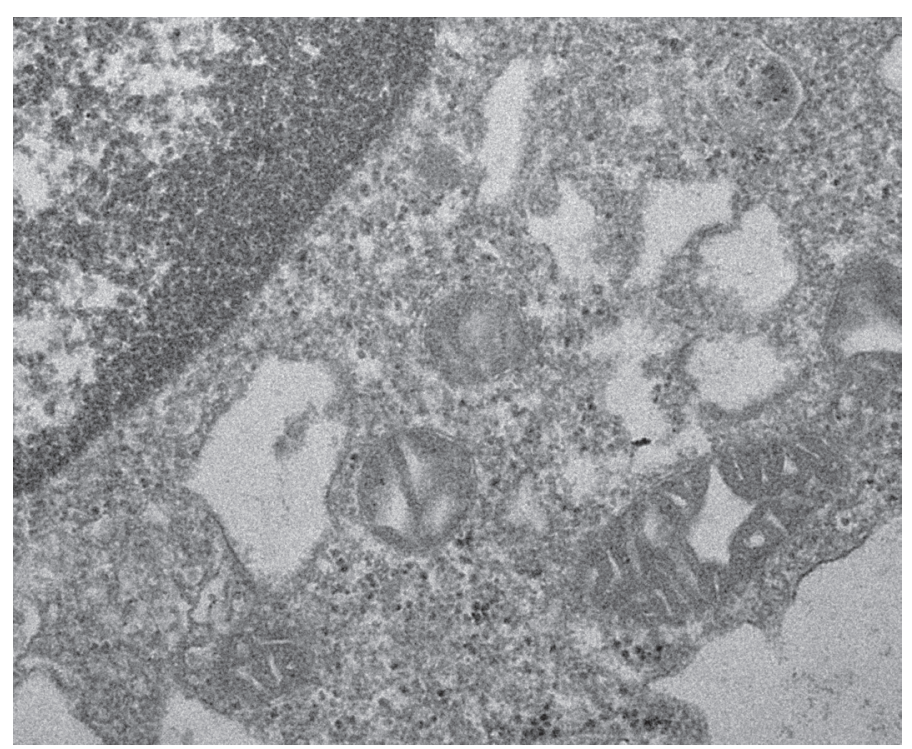

Сурет 2 - Культивирлеуге дейінгі сүйек кемігі жасушалары. Электроннограмма.

Жекелеген вакуольдер құрамы нығыздалған (Руссель денесі). Митохондриялар саны бойынша көп емес, конденсирленген типті және деформацияға ұшыраған кристалары бар.

Мегакриоциттердің көлемі өте үлкен болды. Олардың қасына бөлек тұратын ұсақ ядросыз домалақ нығыз түйіршіктері бар цитоплазма фрагменттері орналасқан, оның ірі вакуольдері мен ұсақ конденсирленген типті, жиектері анық емес митохондриялары бар.

\section{Талқылаулар}

Созылмалы ауыр патологиясы бар науқастардан алынған аутогенді сүйек кемігі жасушалары арасында тиісті морфологиялық құрылымды полиморфизмді діңгек жасушалары сондай - ақ прогениторлы, дифференцирленген жасушалардың гетерогенді популяциялары анықталды. Алайда, жасушалардың әртүрлі морфологиялық класстарға жататындығына қарамастан жасушалар бір бірінен айтарлықтай айқын ультрақұрылыммен ажыратылды. Жасуша ядроларында примаргенальды конденсирленген хроматиннің таралуы байқалады. Ядролы ақуыздық синтездің төмендеуін гранулярлы эндоплазматикалық тор каналдарының кеңеюінен анықтауға болады. Митохондрияларполиморфтықұрылымдыжәнежартыбөлігі тегіс емес кристалы матриксті. Алайда, митохондриялардың басым бөлігі осмиофильді, деструкциялы матриксті, патологиялы өзгеріске ұшыраған конденсирлеген құрылымды болды. Өзгеріске ұшыраған митохондриялар орнына екінші реттік лизосомалар қалыптасқан.

Сонымен, митохондрияларда қышқылды фосфолирлену процесімен қатар конденсирленген типті митохондриялардың айқын дисфункциясы байқалды. Жоғарыда айтылған типті митохондриялар жоғары деңгейлі макроэргиялық құрылымдармен және биоэнергетикалық биосинтетикалық үрдістері белсенді жасушаларда болатыны белгілі [4]. 


\section{Қорытынды}

Қорытындылай келе, ауыр созылмалы патологиялы науқастардан алынған аутологиялық сүйек кемігі жасушаларының морфо-функционалды жағдайы митохондриялық дисфункциямен және микровезикулярлы секреторлы функцияның жетіспеушілігімен сипатталды.
Сондай - ақ аутоиммунды аурулары бар науқастардан алынғын сүйек кемігін прекультивирлеу митохондриялардың энергетикалық қызметін қалпына келтіріп, эндосомалардың секреторлық белсенділігін арттырып, зақымдалған жасушаларды жоюға көмектеседі.

Disclosures: There is no conflict of interest for all authors.

\section{Әдебиеттер тізімі}

1. Sekamova S.M., Beketova T.P. O funkcional'nom znachenii temnyh i svetlyh kletok (About the functional significance of dark and light cells) [in Russian]. Arkhiv patologii.1975;5

2. Klembovskii A.I., Sukhorukov V.S. Problema jenergeticheskoj disfunkcii kletok pri patologii cheloveka (patogenez i korrekcija) (The problem of energy dysfunction of cells in human pathology (pathogenesis and correction) [in Russian]. Vestnik Rossiiskoi akademii estestvennykh nauk. 2007; 62,69

3. Postnov Y.V. O jenergozavisimom zvene patogeneza hronicheskoj gipertenzii (About the energy-dependent link of chronic hypertension pathogenesis)[in Russian]. Arkhiv patologii. 2009;3,11

4. Stepanova O.I., Kasinskaya N.V., Baranova O.V., et al. Metod kul'tivacii i fenotipicheskaja harakteristika gemopojeticheskih kletok kostnogo mozga (mononuklearnoj frakcii) ot donorov s genom zelenogo belka (Method of cultivation and phenotypic characteristic of hematopoietic bone marrow cells (mononuclear fraction) from donors with the gene of green protein [in Russian]. Biomeditsina. 2013;91,94

How to cite this article: Galina Fedotovskikh, Galiya Shaimardanova, Manarbek Askarov, Sapargul Marat, Tatyana Yezhelenko.Ultrastructure of bone marrow cells in patients with autoimmune pathologies [in Kazakh]. J Clin Med Kaz. 2018; 1(47):49-52 